\title{
Viral factors in non-progression
}

\author{
Bin Wang * \\ Sydney Medical School, University of Sydney, Sydney, NSW, Australia
}

\section{Edited by:}

Nitin Kumar Saksena, Westmead Hospital; Westmead Millennium Institute, Australia

\section{Reviewed by:}

Aurelio Cafaro, Istituto Superiore di Sanità, Italy

Velpandi Ayyavoo, University of

Pittsburgh, USA

\section{${ }^{*}$ Correspondence:}

Bin Wang, Retroviral Genetics Laboratory, Center for Virus Research, Westmead Millennium Institute, Westmead, Sydney, NSW 2145, Australia

e-mail: bin.wang@sydney.edu.au

Research has undergone considerable development in understanding a small subset of human immunodeficiency virus type 1 (HIV-1)-infected, therapy-naive individuals who maintain a favorable course of infection surviving for longer periods of time. Although, viral, host genetic, and immunological factors have been analyzed in many previous studies in order to delineate mechanisms that contribute to non-progressive HIV disease, there appears to be a no clear cut winner and the non-progressive HIV disease in $<1 \%$ of HIVinfected individuals appears to be a complex interplay between viral and host factors. Therefore, it is important to review them separately to signify their potential contribution to non-progressive HIV disease. With respect to virological features, genomic sequencing of HIV-1 strains derived from long-term non-progressors has shown that some individuals are infected with attenuated strains of HIV-1 and harbor mutations from single nucleotide polymorphisms to large deletions in HIV-1 structure, regulatory, and accessory genes. The elucidation of functional attributes of defective/attenuated HIV strains may provide better understanding of viral pathogenesis and the discovery of new therapeutic strategies against HIV. This review mainly focuses on the defects in viral genes that possibly guide non-progressive HIV disease.

\section{Keywords: HIV, accessory genes, genetic mutation, non-progressive disease, Nef, vpr}

\section{INTRODUCTION}

Since the beginning of the AIDS epidemic in 1980s', scientists have made great efforts to understand the nature of human immunodeficiency virus (HIV) disease and of its causal agent, the HIV. After primary human immunodeficiency virus type 1 (HIV-1) infection, majority of infected individuals display a gradual decline in peripheral blood $\mathrm{CD}^{+} \mathrm{T}$ lymphocytes throughout the course of the illness accompanied by progressive loss of protective immunity against pathogens (1). However, the natural course of HIV infection such as the progression rates to AIDS and clinical manifestations of diseases associated with infection differs greatly. About $1 \%$ of $\mathrm{HIV}-1^{+}$patients are able to maintain stable $\mathrm{CD} 4^{+} \mathrm{T}$-cell counts within the normal range for a prolonged period of time and remain asymptomatic without anti-retroviral therapy (ART). These HIV1 infected asymptomatic individuals are often referred to as longterm non-progressors (LTNPs). Within this group, a subset of individuals shows plasma HIV-RNA values persistently below detectable level (50 copies $/ \mathrm{ml}$ ), and termed "elite" or "natural controllers" (EC) (2). Study of mechanisms that contribute to nonprogressive HIV disease have revealed complex interplay between viral and host factors. In this section, viral genomic features that associated with benign course of HIV infection will be discussed to delineate our understanding of viral factor in non-progression.

\section{HIV-1 GENOMIC ATTENUATION THAT CONTRIBUTE TO NON-PROGRESSIVE HIV DISEASE}

Human immunodeficiency virus type 1 genome and proteins has been the subject of extensive research since its discovery in 1983 (3). Among nine genes coded by HIV-1, three genes, gag, pol, and env, are found in all retroviruses and are essential to make structural proteins. The other six genes, tat, rev, nef, vif, vpr, and $\mathrm{vpu}$, often described as regulatory and accessory genes, code for proteins that are unique to HIV with important roles on the viral replication and the development of AIDS through many complicated mechanisms. Early identifications of viral attenuation in vitro $(4,5)$ coupled with the observation of low viral loads in vivo and decreased disease progression rate point to the possibility that viruses present in these individuals may be attenuated or defective. Extensive analysis of the HIV-1 genomes, particularly in the regulatory/accessory genes, has shown that certain genetic defects may confer protection to the host.

\section{ACCESSORY GENE ATTENUATION AND DISEASE PROGRESSION}

Although initial thought to be dispensable for infection, HIV-1 accessory proteins have now been considered to be important factors that determine the replication and pathogenesis for efficient infection in vivo.

\section{NEF}

Nef has emerged as one of the most important proteins for viral life cycle and pathogenesis. This accessory protein exhibits a spectrum of biological activities including down-regulation of human leukocyte antigen class I (HLA-I), down-regulation of CD4, enhancement of virion infectivity, and stimulation of viral replication (6-11). Infection by HIV-1 with truncated nef has been shown to contribute to low-level virus replication and nonpathogenicity (12-14). This was further supported by animal study of macaques infected by a nef-deleted SIVmac239 that displayed the absence of disease progression and maintained greatly reduced viral load (15). However, subsequent study using nef-deleted SIVmac239 as live attenuated vaccine fail to demonstrate the safety and efficacy in neonatal macaques (16). In addition to large deletions in nef, single amino acid substitution via point mutation 
that impairs the viral fitness and replication were also reported to slow the disease progression. The detection of significant increased incidence of single amino acid polymorphism at position 138 in LTNPs/SPs (17-19) and the discovery of $40 \%$ of HIV-infected children who experiencing delay disease progression carrying amino acid substitutions at the AWLEAQ (56-61) and the Rxx (2224) domain responsible for the abolishing of CD4 and MHC-1 down-regulations (20) demonstrated functionally defective nef
HIV-1 can be raised without gross gene deletion (Table 1). Mutation studies from several groups have further identified residues involved in nef biological activities such as residues of R25, RD35/36, T80, GL96/97, D108, D111, DW123/124, RY134/135, C142, EE154/155, LL164/165, DD174/175, RRE179, RF184/185 participated in the CD4 down regulation (21-25). Genetic mutations occurred within these residues may potentially disrupt Nef functions and contribute to non-progressive HIV infections.

Table 1 | Summary of HIV-1 genetic mutations that associated with non-progressive HIV disease.

\begin{tabular}{|c|c|c|c|c|}
\hline & & Locations & Functional changes & Reference \\
\hline \multirow{6}{*}{$\begin{array}{l}\text { Structure } \\
\text { genes }\end{array}$} & gag & S67A and D102E & No functional support & Miura et al. (26) \\
\hline & & $\begin{array}{l}\text { Single and double amino acid deletions in gag's p17 } \\
\text { and p6 }\end{array}$ & No functional support & Alexander et al. (27) \\
\hline & & Stop codons in the gag p17 and p27 & No functional support & Wang et al. (28) \\
\hline & pol & M184V/I & Reduced replication capacity & Harrison et al. (29) \\
\hline & env & V2 loop extension & $\begin{array}{l}\text { Restrict the capacity of HIV-1 to replicate in } \\
\text { macrophages }\end{array}$ & $\begin{array}{l}\text { Shioda et al. (30), Wang } \\
\text { et al. (31) }\end{array}$ \\
\hline & & Single amino acid deletion in gp41 & Reduced replication capacity & Alexander et al. (27) \\
\hline \multirow{4}{*}{$\begin{array}{l}\text { Regulatory } \\
\text { genes }\end{array}$} & tat & HIV-1OYI; substitution of cysteine residue for a serine & Unable to trans-activate & Huet et al. (32) \\
\hline & rev & $\begin{array}{l}\text { Three amino acids extension at the } 3^{\prime} \text { end of rev } \\
\text { exon } 2\end{array}$ & No functional support & $\begin{array}{l}\text { Papathanasopoulos et } \\
\text { al. (33) }\end{array}$ \\
\hline & & Polymorphism of codon 78 (L78I) & $\begin{array}{l}\text { Reduce the export of Rev from the nucleus } \\
\text { to the cytoplasm }\end{array}$ & Iversen et al. (34) \\
\hline & & Glu74Pro, Val 104 Leu, and Ser 106 Pro & RRE binding ability & Churchill et al. (35) \\
\hline
\end{tabular}

Accessory vpr Amino acid substitutions at position 72 (F72L)

genes
Amino acid substitutions at position 77 (R77Q)

C-terminus amino acid deletions 83-89

vif 195 nucleotides deletion (aa54-117), insertion in position 63, premature stop codons at positions 70 and 174

V13I, V55T, and L81M

Amino acid substitutions at position (R132S)
Reduce nuclear accumulation and decrease incorporation of vpr into the forming virions Reduce cytopathicity

Defective in nuclear localization; lost ability to induce $\mathrm{G} 2$ arrest and cell death

No functional support

No functional support

Reduced replication capacity
Caly et al. (36)

Lum et al. (37), Mologni et al. (38) Wang et al. (39), Zhao et al. (40)

\section{Rangel et al. (41)}

De Maio et al. (42)

Hassaine et al. (43),

Fujita et al. (44)

\begin{tabular}{ll} 
vpu & Four-amino-acid insertion in the $\mathrm{N}$ terminus \\
\hline nef $\quad 160-430$ nucleotides deletion in nef-LTR region
\end{tabular}

109-139 nucleotides deletion in nef gene and

No functional support

Alexander et al. (27)

Low-level virus replication and reduced

Deacon et al. (12) pathogenicity

No functional support

Salvi et al. (13) 159-204 deletion in nef-LTR region 84 to $>400$ bp nucleotides deletion in nef-LTR region

No functional support

Kondo et al. (14) (CRF01_AE)

Decreased viral replication

Premkumar et al. (17),

Kirchhoff et al. (18);

Tolstrup et al. (19)

Amino acid substitutions at position $22-24$ or 56-61

Corro et al. (20) 


\section{VPR}

The viral protein $\mathrm{R}$ (vpr) of HIV-1 is a highly conserved small basic protein and contributes to viral replication and disease progression in vivo. vpr Functions include G2 cell cycle arrest and apoptosis, T-cell depletion, and nuclear localization of the HIV preintegration complex $(36,37,45)$. vpr Also plays a critical role in long-term AIDS disease by inducing infection in non-dividing cells such as macrophages (46). Functional analysis of vpr protein has provided insights into the biological role played by this protein during the virus life cycle (47-49) and also implied the mutations potentially affect vpr functions. The phenylalanine to leucine mutation at amino acid position 72 (F72L) detected from a non-progressor has been shown to reduce nuclear accumulation and decrease incorporation of vpr into the forming virions (36), while R77Q mutations at the C-terminal conserved motif between 71 and 82 has the ability to reduce cytopathicity and are more frequently detected in LTNPs $(37,38)$. This mutation may also interfere with vpr-mediated cell cycle arrest (Table 1) $(37,38$, 50). The gross defect of vpr gene was uncommon and comparative study of long-term asymptomatics and progressors often showed full-length and intact open reading frames (51) and only an early study reported vpr gene defects clustered at the C-terminus (amino acid 83-89) in long-term non-progressing mother child pair that may potentially affect its secondary structure (39). Subsequent functional analyses of these naturally occurring C-terminus polymorphisms have indicated defective in their ability to localize onto the nuclear envelope, lost ability to induce G2 arrest and lost the ability to induce cell death in some of the clones (Table 1) (40).

\section{VPU}

The $\mathrm{Vpu}$ is a transmembrane protein with a key function in interacting with newly synthesized CD4 molecule in the rough endoplasmic reticulum (RER) resulting in its degradation via the proteasome pathway $(52,53)$. The other functions of $\mathrm{Vpu}$ include enhancement of virion release from virus-producer cells and down-regulation of MHC I and II (54-57).

There is very limited data available on genetic defects in the vpu gene and its association with disease progression as most studies revealed the absence of gross deletions or insertions in the $\mathrm{Vpu}$ derived from LTNPs $(51,58)$. So far, only one non-progressive individual with a four-amino-acid insertion in the $\mathrm{N}$ terminus of $\mathrm{Vpu}$ was reported (27). However, the presence of 4-bp insertion in nef and $3^{\prime}$-LTR sequences resulting the truncation of Nef by one amino acid short of consensus $\mathrm{C}$-terminal cysteine in the same individual made it difficult to determine the significance of $\mathrm{Vpu}$ contribution to the non-progressive status. Interestingly, although there is insufficient patient derived data on Vpu defects and disease progression, it was proposed that lack expression of a functional Vpu protein, such as HIV-2 and most SIV isolates, may be responsible for slower disease progression and cause less disease severity (59).

\section{VIF}

The HIV-1 Vif protein (virion infectivity factor) has a essential role in promoting HIV-1 infectivity by enhancing viral replication and inducing the degradation of the endogenous anti-retroviral factor, apolipoprotein B mRNA editing enzyme catalytic polypeptidelike $3 \mathrm{G}$ (APOBEC3G) $(60,61)$. The importance of vif gene has been well recognized, but only few polymorphisms have been described in possible association with a retarded progression to AIDS. After sequencing vif and nef gene from 14 slow progressors and 46 normal progressors, Rangel et al. revealed the co-circulating of intact and truncated vif gene in one slow progressor. In the same study, the presence of amino acid insertion at position 63 and premature stop codon were also observed in two other slow progressors. But the detection of stop codon in the vif gene in a normal progressive patient with high viral load also suggesting such inhibitory mutations in the vif gene may be less important in virus load reduction (41). A very recent study of a group of 11 children with an extremely slow disease progression found unusual substitutions such as V13I, V55T, and L81M. Databases search suggested an increased frequency of these mutations in sequences from elite controllers (42). Whether these changes linked to Vif functional alternation require further investigations. In addition, R132S substitution has been described to present in LTNP and SP with in vitro evidence of reduced viral replication $(43,44)$. In contrast, one amino acid insertion at position 61 and the substitutions of A62D/N/S and Q136P was indicated to be associated with an accelerated AIDS outcome (62).

\section{REGULATORY GENE ATTENUATION AND HIV DISEASE PROGRESSION}

Tat (Trans-Activator of Transcription) and Rev (Regulator of $V$ irion protein expression) are two essential viral regulatory factors to promote high levels of viral gene expression (63-66). Duo to the function importance, defective HIV-1 rev and tat gene are rarely reported. HIV-1 Tat promotes efficient transcription of the viral genome, which requires structural changes of Tat to bind to a RNA stem-loop structure called TAR (transactivation response element) $(67,68)$. Study of an unusual HIV-1 strain isolated from a healthy Gabonese individual who presented an atypical western blot has revealed functionally defective of Tat resulting from the substitution of an essential cysteine residue for a serine (32). Although the defected Tat has a similar structure to active Tat, it is unable to trans-activate (69). This virus, identified as HIV1OYl, grew to low titers of reverse transcriptase activity, and is lack of obvious cytopathic effect. Important to note that 10 years post infection, 23 of HIV-1 OY1 infected women showed retro conversion and HIV was no longer detectable (70).

In HIV-1 Rev, early study by Iversen et al. (34) revealed the polymorphism of codon 78 (L78I) in the activation domain might contribute to non-progression status (Table 1). Substitutions in this highly conserved leucine-rich activation domain are known to reduce the export of Rev from the nucleus to the cytoplasm (34, 71) and associate with decrease in viremia (72). A three amino acids extension (GlyCysCys) at the $3^{\prime}$ end of rev exon 2 instead of characteristic 16-amino acid truncation commonly shared by HIV subtype C was also reported in HIV-1 subtype C infected slow-progressing siblings (33). In well-characterized Sydney Blood Bank Cohort, in addition to nef attenuation, several members have also displayed functional defect in Rev by evaluation of RRE binding ability (35). Three rare amino acid changes at highly conserved residues (Glu 74 Pro, Val 104 Leu, and Ser 106 Pro) were likely to be associated with such functional defect in two of the cohort's members (Table 1) (35). 


\section{STRUCTURAL GENES AND HIV DISEASE PROGRESSION}

HIV-1 env gene (gp160) product consists of two subunits, gp120 and gp41, and play a crucial role in viral infectivity by binding to CD4 and chemokine receptors expressed on the surface of susceptible cells. The chemokine receptors usage, generally CCR5 and/or CXCR4, are determined largely by amino acid sequence of the variable loop 3 (V3) of gp120 (73). CCR5-using viruses (R5 viruses) are presence in the vast majority of primary infections while a receptor switch toward CXCR 4 occurs in about $50 \%$ of the infected individuals which is associated with increasing in viral load, accelerated CD4 ${ }^{+}$T-cell decline and progression to AIDS (74-76). Therefore, the coreceptor switch could be a key element of HIV pathogenesis and a significant contribution to disease progression. However, the reasons for the coreceptor switch remain poorly understood (77). In LTNPs cohort, HIV-1 strains isolated displayed not only the exclusive CCR5 usage but also decreased entry efficiency suggesting lower env fitness in LTNPs cohort that may contribute to viral suppression (78).

Apart from V3 loop, the sequence changes in the first and second hypervariable loops (V1 and V2) also affect the viral phenotypic property and cellular host range. Several independent studies have shown V2 loop extension in individuals with slow or no disease progression (Table 1) $(30,31)$. This elongation of $\mathrm{V} 2$ may potentially restrict the capacity of $\mathrm{HIV}-1$ to replicate in macrophages (30).

In comparison to HIV-1 gp120, the mutations in the fusion protein subunit gp41 were less frequently reported in their influence in the disease progression rate. A single amino acid deletion in the fusion peptide region of the transmembrane domain in one LTNP was speculated to be responsible for the slow/low growth phenotype of the virus isolated from this individual (27).

\section{GAG AND POL}

Miura et al. studied viral gag sequences from 50 non-progressions and 80 progressors revealed three codon changes $(67 \mathrm{~A}, 102 \mathrm{E}$, and 389I) that were significantly different between the two groups (26). Two of the three codons, S67A and D102E, showed a strong association with the non-progressive HIV disease. However, recombinant viruses with these two mutations failed to provide evidence on the impact of viral replication capacity indicating these differences may merely reflect the historic population consensus amino acid at the time of infection (Table 1) (26). Similarly, functional study of single and double amino acid deletions observed in gag's p17 and p6 from 5 of the LTNPs revealed no difference in facilitating the incorporation of vpr into the HIV-1 particles (27). Apart from the sequence polymorphisms, stop codons in the gag p17, $\mathrm{p} 27$, and in pol RT in proviral DNA from one LTNP have also been reported as a consequence of G-A hypermutation (28). The highly homogeneous sequences with the inactive mutations over 8-year period in this individual suggesting only limited proviral integration events occurred. However, the detection of persist antibody responses to both $\mathrm{p} 17$ and $\mathrm{p} 24$ proteins by western blot during the same period suggesting the presence of intact virions during the course of infection and possible persistent viral replication within some privileged sites (28).

Human immunodeficiency virus type 1 pol gene codes viral enzymes critical for viral replication. It is also the major drug target. Although the emergence of resistance mutations in the pol gene region associated with a reduced sensitivity to anti-retroviral drugs, those resistant mutations often result in the decreased catalytic activity and viral replicative capacity $(79,80)$. Whether the transmission and infections of drug resistant HIV-1 strain with reduced fitness lead to better disease outcome remains as a debatable topic, significantly lower viral load have been found in patients harboring M184V/I when compared to individuals carrying wildtype virus (Table 1) (29). Theoretically infection by viruses with impaired replicative capacity may have less serious impact to the hosts.

\section{THE EFFECT OF DIFFERENT HIV-1 SUBTYPES AND HIV-2 ON DISEASE PROGRESSION RATES}

Much of the understanding of disease progression derives from studies in HIV-1 subtype B strains. However, HIV-1 exhibits a high degree of inter- and intra-subtype genetic diversity (81). Such differences in the genetic characteristics of HIV not only play a role in the dynamics of HIV infection but also influence the biological properties including infectivity, transmissibility, and pathogenicity (82-85). Although there is no data supporting the infection of particular HIV-1 subtype with non-progressive HIV disease, individuals infected by subtype A appear to experience less risk of progression to death compare to non-A subtype (86, 87 ). In contrast, infection by HIV-1 subtype D has been shown to have a higher frequency of syncytium formation and X4 use, and consequently increased risk of progression to death $(83,85)$. Studies of HIV group O and HIV-2 also revealed significant reduced replicative and transmission fitness. This extremely low replicative capacity in comparison with that of HIV-1 group $\mathrm{M}$ strains has led to decreased group $\mathrm{O}$ and HIV-2 transmission and contributes to the low viral load and benign course of infection (88-90).

\section{CONCLUSION}

In conclusion, study the viral factors in non-progression of HIV disease have provided great opportunities in understanding HIV gene functions and their contributions to viral pathogenesis. Genetic defects have been observed in many HIV-1 infected nonprogressors. However, the lack of consistent pattern of genetic features in the LTNPs also suggest that control of HIV replication is not attributable to shared viral genetic defects or shared viral polymorphisms. In addition, it remains unclear how these defective mutations emerged initially and maintained in long-term in the LTNPs. Furthermore, many of the defective mutations are revertible and capable to evolve into virulent phenotype, hence the use of the defective virus as attenuated vaccine strains may not be completely safe. It is also worth to note that it is uncommon to discover defective virus from LTNPs and certain host characteristics need to be considered in the control of slowing disease process. A profound understanding of underlying host factors that force viral attenuation or defects to emerge in LTNPs, will provide new lead to HIV elimination and possible cure.

\section{REFERENCES}

1. Pantaleo G, Fauci AS. Immunopathogenesis of HIV infection. Annu Rev Microbiol (1996) 50:825-54. doi:10.1146/annurev.micro.50.1.825

2. Saksena NK, Rodes B, Wang B, Soriano V. Elite HIV controllers: myth or reality? AIDS Rev (2007) 9:195-207.

3. Barre-Sinoussi F, Chermann JC, Rey F, Nugeyre MT, Chamaret S, Gruest J, et al. Isolation of a T-lymphotropic retrovirus from a patient at risk for 
acquired immune deficiency syndrome (AIDS). Science (1983) 220:868-71. doi:10.1126/science.6189183

4. Learmont J, Tindall B, Evans L, Cunningham A, Cunningham P, Wells J, et al. Long-term symptomless HIV-1 infection in recipients of blood products from a single donor. Lancet (1992) 340:863-7. doi:10.1016/0140-6736(92) 93281-Q

5. Cao Y, Qin L, Zhang L, Safrit J, Ho DD. Virologic and immunologic characterization of long-term survivors of human immunodeficiency virus type 1 infection. N Engl J Med (1995) 332:201-8. doi:10.1056/NEJM199501263320401

6. Mariani R, Skowronski J. CD4 down-regulation by nef alleles isolated from human immunodeficiency virus type 1-infected individuals. Proc Natl Acad Sci U S A (1993) 90:5549-53. doi:10.1073/pnas.90.12.5549

7. Aiken C, Konner J, Landau NR, Lenburg ME, Trono D. Nef induces CD4 endocytosis: requirement for a critical dileucine motif in the membrane-proximal CD4 cytoplasmic domain. Cell (1994) 76:853-64. doi:10.1016/0092-8674(94) 90360-3

8. Anderson SJ, Lenburg M, Landau NR, Garcia JV. The cytoplasmic domain of CD4 is sufficient for its down-regulation from the cell surface by human immunodeficiency virus type 1 Nef. J Virol (1994) 68:3092-101.

9. Miller MD, Warmerdam MT, Gaston I, Greene WC, Feinberg MB. The human immunodeficiency virus-1 nef gene product: a positive factor for viral infection and replication in primary lymphocytes and macrophages. J Exp Med (1994) 179:101-13. doi:10.1084/jem.179.1.101

10. Stoddart CA, Geleziunas R, Ferrell S, Linquist-Stepps V, Moreno ME, Bare C, et al. Human immunodeficiency virus type 1 Nef-mediated downregulation of CD4 correlates with Nef enhancement of viral pathogenesis. J Virol (2003) 77:2124-33. doi:10.1128/JVI.77.3.2124-2133.2003

11. Munch J, Rajan D, Schindler M, Specht A, Rucker E, Novembre FJ, et al. Nefmediated enhancement of virion infectivity and stimulation of viral replication are fundamental properties of primate lentiviruses. J Virol (2007) 81:13852-64. doi:10.1128/JVI.00904-07

12. Deacon NJ, Tsykin A, Solomon A, Smith K, Ludford-Menting M, Hooker DJ, et al. Genomic structure of an attenuated quasi species of HIV-1 from a blood transfusion donor and recipients. Science (1995) 270:988-91. doi:10.1126/science. 270.5238 .988

13. Salvi R, Garbuglia AR, Di Caro A, Pulciani S, Montella F, Benedetto A. Grossly defective nef gene sequences in a human immunodeficiency virus type 1seropositive long-term nonprogressor. J Virol (1998) 72:3646-57.

14. Kondo M, Shima T, Nishizawa M, Sudo K, Iwamuro S, Okabe T, et al. Identification of attenuated variants of HIV-1 circulating recombinant form 01_AE that are associated with slow disease progression due to gross genetic alterations in the nef/long terminal repeat sequences. J Infect Dis (2005) 192:56-61. doi: $10.1086 / 430739$

15. Kestler HW III, Ringler DJ, Mori K, Panicali DL, Sehgal PK, Daniel MD, et al. Importance of the nef gene for maintenance of high virus loads and for development of AIDS. Cell (1991) 65:651-62. doi:10.1016/0092-8674(91)90097-I

16. Baba TW, Jeong YS, Pennick D, Bronson R, Greene MF, Ruprecht RM. Pathogenicity of live, attenuated SIV after mucosal infection of neonatal macaques. Science (1995) 267:1820-5. doi:10.1126/science.7892606

17. Premkumar DR, Ma XZ, Maitra RK, Chakrabarti BK, Salkowitz J, Yen-Lieberman $\mathrm{B}$, et al. The nef gene from a long-term HIV type 1 nonprogressor. AIDS Res Hum Retroviruses (1996) 12:337-45. doi:10.1089/aid.1996.12.337

18. Kirchhoff F, Easterbrook PJ, Douglas N, Troop M, Greenough TC, Weber J, et al. Sequence variations in human immunodeficiency virus type $1 \mathrm{Nef}$ are associated with different stages of disease. J Virol (1999) 73:5497-508.

19. Tolstrup M, Laursen AL, Gerstoft J, Pedersen FS, Ostergaard L, Duch M. Cysteine 138 mutation in HIV-1 Nef from patients with delayed disease progression. Sex Health (2006) 3:281-6. doi:10.1071/SH06002

20. Corro G, Rocco CA, De Candia C, Catano G, Turk G, Mangano A, et al. Genetic and functional analysis of HIV type 1 nef gene derived from longterm nonprogressor children: association of attenuated variants with slow progression to pediatric AIDS. AIDS Res Hum Retroviruses (2012) 28:1617-26. doi:10.1089/AID.2012.0020

21. Aiken C, Krause L, Chen YL, Trono D. Mutational analysis of HIV-1 Nef: identification of two mutants that are temperature-sensitive for CD4 downregulation. Virology (1996) 217:293-300. doi:10.1006/viro.1996.0116

22. Hua J, Blair W, Truant R, Cullen BR. Identification of regions in HIV-1 Nef required for efficient downregulation of cell surface CD4. Virology (1997) 231:231-8. doi:10.1006/viro.1997.8517
23. Hua J, Cullen BR. Human immunodeficiency virus types 1 and 2 and simian immunodeficiency virus Nef use distinct but overlapping target sites for downregulation of cell surface CD4. J Virol (1997) 71:6742-8.

24. Iafrate AJ, Bronson S, Skowronski J. Separable functions of Nef disrupt two aspects of T cell receptor machinery: CD4 expression and CD3 signaling. EMBO $J$ (1997) 16:673-84. doi:10.1093/emboj/16.4.673

25. Hanna Z, Priceputu E, Hu C, Vincent P, Jolicoeur P. HIV-1 Nef mutations abrogating downregulation of CD4 affect other Nef functions and show reduced pathogenicity in transgenic mice. Virology (2006) 346:40-52. doi:10.1016/j.virol. 2005.10.010

26. Miura T, Brockman MA, Brumme CJ, Brumme ZL, Carlson JM, Pereyra F, et al. Genetic characterization of human immunodeficiency virus type 1 in elite controllers: lack of gross genetic defects or common amino acid changes. J Virol (2008) 82:8422-30. doi:10.1128/JVI.00535-08

27. Alexander L, Weiskopf E, Greenough TC, Gaddis NC, Auerbach MR, Malim MH, et al. Unusual polymorphisms in human immunodeficiency virus type 1 associated with nonprogressive infection. J Virol (2000) 74:4361-76. doi:10.1128/JVI. 74.9.4361-4376.2000

28. Wang B, Mikhail M, Dyer WB, Zaunders JJ, Kelleher AD, Saksena NK. First demonstration of a lack of viral sequence evolution in a nonprogressor, defining replication-incompetent HIV-1 infection. Virology (2003) 312:135-50. doi:10.1016/S0042-6822(03)00159-4

29. Harrison L, Castro H, Cane P, Pillay D, Booth C, Phillips A, et al. The effect of transmitted HIV-1 drug resistance on pre-therapy viral load. AIDS (2010) 24:1917-22. doi:10.1097/QAD.0b013e32833c1d93

30. Shioda T, Oka S, Xin X, Liu H, Harukuni R, Kurotani A, et al. In vivo sequence variability of human immunodeficiency virus type 1 envelope gp 120: association of V2 extension with slow disease progression. J Virol (1997) 71:4871-81.

31. Wang B, Spira TJ, Owen S, Lal RB, Saksena NK. HIV-1 strains from a cohort of American subjects reveal the presence of a V2 region extension unique to slow progressors and non-progressors. AIDS (2000) 14:213-23. doi:10.1097/00002030-200002180-00002

32. Huet T, Dazza MC, Brun-Vezinet F, Roelants GE, Wain-Hobson S. A highly defective HIV-1 strain isolated from a healthy Gabonese individual presenting an atypical western blot. AIDS (1989) 3:707-15. doi:10.1097/00002030198911000-00004

33. Papathanasopoulos MA, Patience T, Meyers TM, Mccutchan FE, Morris L. Fulllength genome characterization of HIV type 1 subtype $\mathrm{C}$ isolates from two slow-progressing perinatally infected siblings in South Africa. AIDS Res Hum Retroviruses (2003) 19:1033-7. doi:10.1089/088922203322588396

34. Iversen AK, Shpaer EG, Rodrigo AG, Hirsch MS, Walker BD, Sheppard HW, et al. Persistence of attenuated rev genes in a human immunodeficiency virus type 1-infected asymptomatic individual. J Virol (1995) 69:5743-53.

35. Churchill MJ, Chiavaroli L, Wesselingh SL, Gorry PR. Persistence of attenuated HIV-1 rev alleles in an epidemiologically linked cohort of long-term survivors infected with nef-deleted virus. Retrovirology (2007) 4:43. doi:10.1186/17424690-4-43

36. Caly L, Saksena NK, Piller SC, Jans DA. Impaired nuclear import and viral incorporation of $\mathrm{Vpr}$ derived from a HIV long-term non-progressor. Retrovirology (2008) 5:67. doi:10.1186/1742-4690-5-67

37. Lum JJ, Cohen OJ, Nie Z, Weaver JG, Gomez TS, Yao XJ, et al. Vpr R77Q is associated with long-term nonprogressive HIV infection and impaired induction of apoptosis. J Clin Invest (2003) 111:1547-54. doi:10.1172/JCI16233

38. Mologni D, Citterio P, Menzaghi B, Zanone Poma B, Riva C, Broggini V, et al. Vpr and HIV-1 disease progression: R77Q mutation is associated with longterm control of HIV-1 infection in different groups of patients. AIDS (2006) 20:567-74. doi:10.1097/01.aids.0000210611.60459.0e

39. Wang B, Ge YC, Palasanthiran P, Xiang SH, Ziegler J, Dwyer DE, et al. Gene defects clustered at the C-terminus of the vpr gene of HIV-1 in long-term nonprogressing mother and child pair: in vivo evolution of vpr quasispecies in blood and plasma. Virology (1996) 223:224-32. doi:10.1006/viro.1996.0471

40. Zhao YQ, Chen MZ, Wang B, Yang J, Elder RT, Song XQ, et al. Functional conservation of HIV-1 Vpr and variability in a mother-child pair of long-term nonprogressors. Virus Res (2002) 89:103-21. doi:10.1016/S0168-1702(02)00127-2

41. Rangel HR, Garzaro D, Rodriguez AK, Ramirez AH, Ameli G, Gutierrez CD, et al. Deletion, insertion and stop codon mutations in vif genes of HIV-1 infecting slow progressor patients. J Infect Dev Ctries (2009) 3:531-8. doi:10.3855/jidc.471

42. De Maio FA, Rocco CA, Aulicino PC, Bologna R, Mangano A, Sen L. Unusual substitutions in HIV-1 vif from children infected perinatally without progression 
to AIDS for more than 8 years without therapy. J Med Virol (2012) 84:1844-52. doi:10.1002/jmv.23261

43. Hassaine G, Agostini I, Candotti D, Bessou G, Caballero M, Agut H, et al. Characterization of human immunodeficiency virus type 1 vif gene in long-term asymptomatic individuals. Virology (2000) 276:169-80. doi:10.1006/viro.2000. 0543

44. Fujita M, Sakurai A, Yoshida A, Matsumoto S, Miyaura M, Adachi A. Subtle mutations in the cysteine region of HIV-1 Vif drastically alter the viral replication phenotype. Microbes Infect (2002) 4:621-4. doi:10.1016/S1286-4579(02)01580-0

45. Jowett JB, Planelles V, Poon B, Shah NP, Chen ML, Chen IS. The human immunodeficiency virus type 1 vpr gene arrests infected T cells in the G2 + M phase of the cell cycle. J Virol (1995) 69:6304-13.

46. Heinzinger NK, Bukinsky MI, Haggerty SA, Ragland AM, Kewalramani V, Lee MA, et al. The Vpr protein of human immunodeficiency virus type 1 influences nuclear localization of viral nucleic acids in nondividing host cells. Proc Natl Acad Sci U S A (1994) 91:7311-5. doi:10.1073/pnas.91.15.7311

47. Schuler W, Wecker K, De Rocquigny H, Baudat Y, Sire J, Roques BP. NMR structure of the (52-96) C-terminal domain of the HIV-1 regulatory protein Vpr: molecular insights into its biological functions. J Mol Biol (1999) 285:2105-17. doi:10.1006/jmbi.1998.2381

48. Wecker K, Roques BP. NMR structure of the (1-51) N-terminal domain of the HIV-1 regulatory protein Vpr. Eur J Biochem (1999) 266:359-69. doi:10.1046/j. 1432-1327.1999.00858.x

49. Wecker K, Morellet N, Bouaziz S, Roques BP. NMR structure of the HIV-1 regulatory protein $\mathrm{Vpr}$ in $\mathrm{H} 2 \mathrm{O}$ /trifluoroethanol. Comparison with the $\mathrm{Vpr} \mathrm{N}$-terminal (1-51) and C-terminal (52-96) domains. Eur J Biochem (2002) 269:3779-88. doi:10.1046/j.1432-1033.2002.03067.x

50. Rajan D, Wildum S, Rucker E, Schindler M, Kirchhoff F. Effect of R77Q, R77A and R80A changes in Vpr on HIV-1 replication and CD4 T cell depletion in human lymphoid tissue ex vivo. AIDS (2006) 20:831-6. doi:10.1097/01.aids. $0000218546.31716 .7 \mathrm{f}$

51. Cornelissen M, Kuiken C, Zorgdrager F, Hartman S, Goudsmit J. Gross defects in the vpr and vpu genes of HIV type 1 cannot explain the differences in RNA copy number between long-term asymptomatics and progressors. AIDS Res Hum Retroviruses (1997) 13:247-52. doi:10.1089/aid.1997.13.247

52. Chen MY, Maldarelli F, Karczewski MK, Willey RL, Strebel K. Human immunodeficiency virus type $1 \mathrm{Vpu}$ protein induces degradation of CD4 in vitro: the cytoplasmic domain of CD4 contributes to Vpu sensitivity. J Virol (1993) 67:3877-84.

53. Bour S, Schubert U, Strebel K. The human immunodeficiency virus type $1 \mathrm{Vpu}$ protein specifically binds to the cytoplasmic domain of CD4: implications for the mechanism of degradation. J Virol (1995) 69:1510-20.

54. Kerkau T, Bacik I, Bennink JR, Yewdell JW, Hunig T, Schimpl A, et al. The human immunodeficiency virus type 1 (HIV-1) Vpu protein interferes with an early step in the biosynthesis of major histocompatibility complex (MHC) class I molecules. J Exp Med (1997) 185:1295-305. doi:10.1084/jem.185.7.1295

55. Hussain A, Wesley C, Khalid M, Chaudhry A, Jameel S. Human immunodeficiency virus type $1 \mathrm{Vpu}$ protein interacts with CD74 and modulates major histocompatibility complex class II presentation. J Virol (2008) 82:893-902. doi:10.1128/JVI.01373-07

56. Neil SJ, Zang T, Bieniasz PD. Tetherin inhibits retrovirus release and is antagonized by HIV-1 Vpu. Nature (2008) 451:425-30. doi:10.1038/nature06553

57. Nomaguchi M, Fujita M, Adachi A. Role of HIV-1 Vpu protein for virus spread and pathogenesis. Microbes Infect (2008) 10:960-7. doi:10.1016/j.micinf.2008. 07.006

58. Zhang L, Huang Y, Yuan H, Tuttleton S, Ho DD. Genetic characterization of vif, vpr, and vpu sequences from long-term survivors of human immunodeficiency virus type 1 infection. Virology (1997) 228:340-9. doi:10.1006/viro.1996.8378

59. Leligdowicz A, Rowland-Jones S. Tenets of protection from progression to AIDS: lessons from the immune responses to HIV-2 infection. Expert Rev Vaccines (2008) 7:319-31. doi:10.1586/14760584.7.3.319

60. Sheehy AM, Gaddis NC, Choi JD, Malim MH. Isolation of a human gene that inhibits HIV-1 infection and is suppressed by the viral Vif protein. Nature (2002) 418:646-50. doi:10.1038/nature00939

61. Zhang WY, Chen GY, Niewiadomska AM, Xu RZ, Yu XF. Distinct determinants in HIV-1 Vif and human APOBEC3 proteins are required for the suppression of diverse host anti-viral proteins. PLoS One (2008) 3:e3963. doi:10.1371/journal.pone.0003963
62. De Maio FA, Rocco CA, Aulicino PC, Bologna R, Mangano A, Sen L. Effect of HIV-1 Vif variability on progression to pediatric AIDS and its association with APOBEC3G and CUL5 polymorphisms. Infect Genet Evol (2011) 11:1256-62. doi:10.1016/j.meegid.2011.04.020

63. Hauber J, Perkins A, Heimer EP, Cullen BR. Trans-activation of human immunodeficiency virus gene expression is mediated by nuclear events. Proc Natl Acad Sci U S A (1987) 84:6364-8. doi:10.1073/pnas.84.18.6364

64. Malim MH, Tiley LS, Mccarn DF, Rusche JR, Hauber J, Cullen BR. HIV-1 structural gene expression requires binding of the Rev trans-activator to its RNA target sequence. Cell (1990) 60:675-83. doi:10.1016/0092-8674(90)90670-A

65. Richard N, Iacampo S, Cochrane A. HIV-1 Rev is capable of shuttling between the nucleus and cytoplasm. Virology (1994) 204:123-31. doi:10.1006/viro.1994. 1516

66. Pollard VW, Malim MH. The HIV-1 Rev protein. Annu Rev Microbiol (1998) 52:491-532. doi:10.1146/annurev.micro.52.1.491

67. Berkhout B, Gatignol A, Rabson AB, Jeang KT. TAR-independent activation of the HIV-1 LTR: evidence that tat requires specific regions of the promoter. Cell (1990) 62:757-67. doi:10.1016/0092-8674(90)90120-4

68. Loret EP, Georgel P, Johnson WC Jr, Ho PS. Circular dichroism and molecular modeling yield a structure for the complex of human immunodeficiency virus type 1 trans-activation response RNA and the binding region of Tat, the transacting transcriptional activator. Proc Natl Acad Sci U S A (1992) 89:9734-8. doi:10.1073/pnas.89.20.9734

69. Peloponese JM Jr, Collette Y, Gregoire C, Bailly C, Campese D, Meurs EF, et al. Full peptide synthesis, purification, and characterization of six Tat variants. Differences observed between HIV-1 isolates from Africa and other continents. J Biol Chem (1999) 274:11473-8. doi:10.1074/jbc.274.17.11473

70. Watkins JD, Lancelot S, Campbell GR, Esquieu D, De Mareuil J, Opi S, et al. Reservoir cells no longer detectable after a heterologous SHIV challenge with the synthetic HIV-1 Tat Oyi vaccine. Retrovirology (2006) 3:8. doi:10.1186/1742-4690-3-S1-P8

71. Malim MH, Mccarn DF, Tiley LS, Cullen BR. Mutational definition of the human immunodeficiency virus type 1 Rev activation domain. J Virol (1991) 65:4248-54.

72. Svicher V, Alteri C, D’Arrigo R, Lagana A, Trignetti M, Lo Caputo S, et al. Treatment with the fusion inhibitor enfuvirtide influences the appearance of mutations in the human immunodeficiency virus type 1 regulatory protein rev. Antimicrob Agents Chemother (2009) 53:2816-23. doi:10.1128/AAC.0106708

73. Briggs DR, Tuttle DL, Sleasman JW, Goodenow MM. Envelope V3 amino acid sequence predicts HIV-1 phenotype (co-receptor usage and tropism for macrophages). AIDS (2000) 14:2937-9. doi:10.1097/00002030-20001222000016

74. Koot M, Van 'T Wout AB, Kootstra NA, De Goede RE, Tersmette M, Schuitemaker $H$. Relation between changes in cellular load, evolution of viral phenotype, and the clonal composition of virus populations in the course of human immunodeficiency virus type 1 infection. J Infect Dis (1996) 173:349-54. doi:10.1093/infdis/173.2.349

75. Daar ES, Kesler KL, Petropoulos CJ, Huang W, Bates M, Lail AE, et al. Baseline HIV type 1 coreceptor tropism predicts disease progression. Clin Infect Dis (2007) 45:643-9. doi:10.1086/520650

76. Goetz MB, Leduc R, Kostman JR, Labriola AM, Lie Y, Weidler J, et al. Relationship between HIV coreceptor tropism and disease progression in persons with untreated chronic HIV infection. J Acquir Immune Defic Syndr (2009) 50:259-66. doi:10.1097/QAI.0b013e3181989a8b

77. Regoes RR, Bonhoeffer S. The HIV coreceptor switch: a population dynamical perspective. Trends Microbiol (2005) 13:269-77. doi:10.1016/j.tim.2005.04. 005

78. Lassen KG, Lobritz MA, Bailey JR, Johnston S, Nguyen S, Lee B, et al. Elite suppressor-derived HIV-1 envelope glycoproteins exhibit reduced entry efficiency and kinetics. PLoS Pathog (2009) 5:e1000377. doi:10.1371/journal.ppat. 1000377

79. Croteau G, Doyon L, Thibeault D, Mckercher G, Pilote L, Lamarre D. Impaired fitness of human immunodeficiency virus type 1 variants with high-level resistance to protease inhibitors. J Virol (1997) 71:1089-96.

80. Martinez-Picado J, Martinez MA. HIV-1 reverse transcriptase inhibitor resistance mutations and fitness: a view from the clinic and ex vivo. Virus Res (2008) 134:104-23. doi:10.1016/j.virusres.2007.12.021 
81. McCutchan FE. Understanding the genetic diversity of HIV-1. AIDS (2000) 14(Suppl 3):S31-44.

82. De Wolf F, Hogervorst E, Goudsmit J, Fenyo EM, Rubsamen-Waigmann H, Holmes H, et al. Syncytium-inducing and non-syncytium-inducing capacity of human immunodeficiency virus type 1 subtypes other than B: phenotypic and genotypic characteristics. WHO Network for HIV Isolation and Characterization. AIDS Res Hum Retroviruses (1994) 10:1387-400. doi:10.1089/aid.1994.10. 1387

83. Tscherning C, Alaeus A, Fredriksson R, Bjorndal A, Deng H, Littman DR, et al. Differences in chemokine coreceptor usage between genetic subtypes of HIV-1. Virology (1998) 241:181-8. doi:10.1006/viro.1997.8980

84. Kaleebu P, French N, Mahe C, Yirrell D, Watera C, Lyagoba F, et al. Effect of human immunodeficiency virus (HIV) type 1 envelope subtypes A and D on disease progression in a large cohort of HIV-1-positive persons in Uganda. $J$ Infect Dis (2002) 185:1244-50. doi:10.1086/340130

85. Kaleebu P, Nankya IL, Yirrell DL, Shafer LA, Kyosiimire-Lugemwa J, Lule DB, et al. Relation between chemokine receptor use, disease stage, and HIV-1 subtypes A and D: results from a rural Ugandan cohort. J Acquir Immune Defic Syndr (2007) 45:28-33. doi:10.1097/QAI. 0b013e3180385aa0

86. Kanki PJ, Hamel DJ, Sankale JL, Hsieh C, Thior I, Barin F, et al. Human immunodeficiency virus type 1 subtypes differ in disease progression. J Infect Dis (1999) 179:68-73. doi:10.1086/314557

87. Kiwanuka N, Laeyendecker O, Robb M, Kigozi G, Arroyo M, Mccutchan F, et al. Effect of human immunodeficiency virus Type 1 (HIV-1) subtype on disease progression in persons from Rakai, Uganda, with incident HIV-1 infection. J Infect Dis (2008) 197:707-13. doi:10.1086/527416
88. Kanki PJ, Travers KU, MBoup S, Hsieh CC, Marlink RG, Gueye NA, et al. Slower heterosexual spread of HIV-2 than HIV-1. Lancet (1994) 343:943-6. doi:10.1016/S0140-6736(94)90065-5

89. Marlink R, Kanki P, Thior I, Travers K, Eisen G, Siby T, et al. Reduced rate of disease development after HIV-2 infection as compared to HIV-1. Science (1994) 265:1587-90. doi:10.1126/science.7915856

90. Arien KK, Abraha A, Quinones-Mateu ME, Kestens L, Vanham G, Arts EJ. The replicative fitness of primary human immunodeficiency virus type 1 (HIV1) group M, HIV-1 group O, and HIV-2 isolates. J Virol (2005) 79:8979-90. doi:10.1128/JVI.79.14.8979-8990.2005

Conflict of Interest Statement: The author declares that the research was conducted in the absence of any commercial or financial relationships that could be construed as a potential conflict of interest.

Received: 22 March 2013; paper pending published: 08 April 2013; accepted: 21 October 2013; published online: 24 December 2013.

Citation: Wang B (2013) Viral factors in non-progression. Front. Immunol. 4:355. doi: 10.3389/fimmu.2013.00355

This article was submitted to HIV and AIDS, a section of the journal Frontiers in Immunology.

Copyright (c) 2013 Wang. This is an open-access article distributed under the terms of the Creative Commons Attribution License (CC BY). The use, distribution or reproduction in other forums is permitted, provided the original author(s) or licensor are credited and that the original publication in this journal is cited, in accordance with accepted academic practice. No use, distribution or reproduction is permitted which does not comply with these terms. 